\title{
The Journey of Islamic Art Through Traditional and Contemporary Calligraphy Painting
}

\author{
Duaa Mohammed Alashari ${ }^{*}$, Abd.Rahman Hamzah, Nurazmallail Marni \\ Faculty of Islamic Civilization, Universiti Teknologi Malaysia, 81310 UTM Johor Bahru, Johor, Malaysia \\ *Corresponding author:duaa1983@graduate.utm.my
}

\author{
Article history \\ Received: 2019-11-27 Received in revised form: 2020-04-02 Accepted: 2020-04-05 Published online: 2020-10-30
}

\begin{abstract}
Islamic Art is considered as historical art and it is famous all over the Islamic world. The Islamic calligraphy art started around the time of the revelation of al-Quran. Islamic calligraphy art was famous for adorning the interior and exterior aspects of mosques and some famous Islamic buildings. The aim of this article is to highlight and study the traditional and contemporary Islamic calligraphy painting by well-known calligraphers. Calligraphers have been inspired by the Arabic language and they are expressing this language as a kind of unique art through traditional and contemporary painting. Indeed, this paper will provide a brief history of calligraphy art. Islamic calligraphy painting is expressed in a variety of styles and there are also different modes of traditional Arabic styles of writing. Islamic Calligraphers appreciate this sacred and spiritual art and as they carried on their journey, they began to create their art by adding some inspirational verses of the Quran as well as some historical poems. The most noticeable visible feature related to Islamic calligraphy traditional and contemporary painting has to do with the complex and intricate compositions that involve the overlapping of words integrated into a unique method. Islamic calligraphy painting, through either a traditional or a contemporary method, expresses movement and dynamism through the calligraphic lines. The study reveals that the traditional and contemporary calligraphy paintings are considered as innovative art based on their unique traditional scripts, the intricate contemporary identity of the handwriting and the materials. Calligraphers expressed their artistry, and their ability and creativity by applying the sacred language to create a fabulous and unique tradition which is referred to as contemporary calligraphy painting.
\end{abstract}

Keywords: Islamic painting, Arabic Calligraphy, Islamic Art, Arabic language, contemporary painting. 


\subsection{INTRODUCTION}

Islamic art suggests a unity of style and purpose (Brend, 1991:p7). Islamic calligraphy was venerated as a kind of spiritual art and has been considered as a sacred form of art by Muslims for a long time. Calligraphy is kind of script that appeared after the revolution of the Quran. The meaning and significance of Islamic calligraphy has to do with writing Arabic letters and words in an artistic way. The holy book, the Quran, which dates back seven centuries, was written down in the Arabic language. In fact, Islamic calligraphy developed for the purpose of writing the Quran in a noble and beautiful style. Islamic calligraphy painting has a special appearance compared to other kinds of calligraphy painting found around the world. Moreover, calligraphy painting reflects the history and the diversity of Islamic civilization. Calligraphers, inspired by the Arabic language, were directed to create a fabulous traditional and contemporary calligraphy painting, that expresses the aesthetic and spiritual aspect of Islamic art.

Calligraphy painting is a kind of artistic experience that is presented using Arabic letters, words and colours. Traditional and contemporary calligraphers create their work based on the sacred words of the Quran through meditating on the meaning behind the verses. Also, some words of the prophet Mohammed are known as "hadith", and this is also true for some historical poems.

Islamic calligraphy painting utilized the Arabic language from a different perspective. However, all tradition and contemporaries' calligraphers recreated their painting based on the Islamic calligraphy style of writing as a starting point and as a source of inspiration. Traditional and contemporary calligraphy painting expressed the concept of the heritage of the Arabic language. In general, traditional and contemporary calligraphy painting presents the perspective of a unique and complex composition of Islamic art.

Islamic art represents an infinite sense of spirituality through the calligraphy painting. The famous feature about calligraphy painting in the traditional or modern method has to do with applying the principle of design, such as, repetition, unity, rhythm, and balance. Calligraphers have been influenced strongly by Islamic heritage to form their painting. In traditional painting the calligraphers must follow Arabic role for writing, and this involves the strict rules and principles of writing as well as using certain traditional tools and techniques. On the other hand, in contemporary painting calligraphers use modern materials and they do not follow any style or rule to draw the calligraphy to create their painting. Also, contemporary calligraphy painting utilises a variety of methods and it is not bound to the rules of tradition. In general, calligraphy painting conveys a sense of universal spirituality and presents the sacred language that preserves the word of God.

Examples of traditional calligraphy can be seen on the interiors and exteriors of mosques all over the Islamic world as well as the beautiful and amazing calligraphy that is presented on the Kiswah of the Kabah. This calligraphy script that adorns the surface represents the power of the Islamic faith and conveys the divine message of the Quran. Moreover, contemporary calligraphy painting conveys the spirituality and the aesthetic dimension of the Arabic language in a unique style by depicting the form of the letters. 


\subsection{THE BRIEF HISTORY OF ISLAMIC CALLIGRAPHY ART}

Islamic calligraphy started in the seventh century and continues to the late twentieth century. The far-reaching geographical sphere of the Islamic world presents a variety of styles for writing Islamic calligraphy. Each culture where Islam endures the artists have developed their own styles and tools to create their Islamic calligraphy. Islamic calligraphy is signified by a geometric way of writing. The Islamic language developed from the Semitic alphabet (Brend,1991,p37).

Barbara Brend states that $(1991, \mathrm{p} 10)$ "the term Islamic art suggests a unity of style and purpose, and these works are in fact instantly recognizable for their subtlety of lines and sumptuous details. The Islamic world from Arabia to North Africa and Spain, from Turkey to Asia and India has a shared cultural heritage of extraordinary richness."

The prophet Mohammed encourages both men and women to read and write. During prophet Muhammad's life his followers began to read and write the Quran, including the four early caliphs. The fourth caliph, Ail, was considered as the first master of Islamic calligraphy (Schimmel,1970:p54). By the end of his life, about thirty thousand contemporaries of his had heard and memorized the Quran in its entirety (Faruqi, Lois,1986:p85).

Zakariya (2002, p9) states that "one cannot precisely ascertain or describe how the early writing look[ed], but the earliest written forms can only be guessed. Inscriptions on stone suggested both unconnected and connected letter alphabets were in use. The connected letter alphabet is recognizable as the true Arabic alphabet". Zakariya continues that "it was on record and established that fewer people in the Prophet Muhammad's (P.B.U.H) lifetime knew how to read and write. He also had scribes, to write for him, as he was unlettered."

The Quran and its language inspired a civilization and culture that adopted the Islam religion. Then Arabic became a universal language that was practiced by Muslims all over the Islamic world. Islamic calligraphy was developing some ways of writing to emphasize the verses of the Quran, and the main concern of calligraphers is to focus on the aspect of aesthetics and perfection. In the early Islamic era calligraphers held a high position in society and their mission was combining the aesthetic element of writing so it appeared along with the spiritual aspect.

An example of early Islamic calligraphy is represented on the monuments of the Umayyads. There are many examples that present the earlier calligraphy, such as, the Dome of Rock in Jerusalem. The Dome of Rock is considered as an evolving art of calligraphy. According to Barbara Brend (1991:p89) Islamic calligraphy is considered as a supreme art all over the Islamic world, and writing became comparable to that which is sacramental because it conveys the word of Allah.

In the Umayyad era, calligraphers began to improve the writing of the Quran. Ibrahim alShajari, developed the pen of the two-thirds. The well-known Umayyad calligrapher, Hassan AlBasri, was born in Basra and he passed away in Basra. The Islamic calligraphy during the Umayyad period distanced from the development and reached the Abbasid period with some invented style. After the Umayyad era, the center of calligraphy became the city of Baghdad. This city was founded by Abu Jaafar al-Mansur during the Abbasid era, and many calligraphers emerged from Baghdad, such as, Dahak bin Ajlan and Ishaq bin Hammad. Dahak bin Ajlan and Ishaq bin Hammad became the earlier calligraphers from the Abbasid era.

During the Abbasid era, Islamic calligraphy and calligraphers became a place of great importance and status. The function of the Islamic calligraphers became one of the most important functions at the level of the state. The calligraphers invented writing on the walls of Islamic 
architectural monuments, such as, mosques and palaces. The leader of Islamic calligraphers from the Abbasi's ear was Ibn Muqla. Ibn Makla appeared, as a calligrapher from Baghdad city, and one of his accomplishments involved creating the precise measurements and rules for writing Arabic calligraphy. This rule is referred to as the "golden virtues". He also improved the quality of the line, so it was smoother. According to Brend (1991, p65) " Inb Muqlah evolved a system for the evaluation of the proportions of scripts; it was based upon a dot the square of the pen width, the simple vertical of Alif, the first letter, and a circle of the diameter of Alif".

After the calligrapher Ibn Makla, another great calligrapher appeared, known by the name of Yaqut al-Musta'simi worked diligently and he excelled in the quality of the pen as well as in the style of writing calligraphy. Also, Ibn al-Bawwab, contributed to the style of calligraphy and he learned his calligraphy from Inb Muqlah. Ibn Muqla, Ibn al-Bawwab, and Yaqut al-Mustasimi are pioneers of the set of the rule of calligraphy and are famous and celebrated even today. Islamic calligraphers during the Abbasid era were working to improve and continue to advance Islamic calligraphy style and tools. Brend (1991, p123) states that " curvilinear scripts for secular purposes were developed in the chanceries of the Umayyads and the Abbasids".

The scripts developed to six styles that include the Naskhi, Thuluth, Muhaqqaq, Rajdhani, Riq'ah and the Tauqi' style. The most important styles of writing include the Naskhi, Thuluth and the Muhaqqaq styles. Most of the great calligraphers of the Abbasids have practiced the six styles of calligraphy. In terms of the Naskhi style, it had been elevated by the proportional approach of Ibn Muqlah. Even so, Ibn al-Bawwab refined the style of Naskhi much further, so the style became a strong and supple medium of great clarity. Naskhi was utilized for copying the Quran and it continues for this purpose. The Thuluth style was developed under the hand of Ibn Muqlah. Brend (1991, p34) states that "thuluth was an ornamental script used for heading or tile inscriptions which required a striking effect over a limited length." As for the Muhaqqaq style, it is associated with writing most of the qur'anic scripts from the Mamluk period.

After the Abbasid era, the Othman era started in 644, and the script of writing the Quran was developed around this time (Brend,1991, p54). Ottoman calligraphers were considered as the greatest artists of the Islamic period. The sultans of Ottoman loved calligraphy and considered themselves as students and they wanted to learn calligraphy from the calligraphers. The calligrapher Yaqut al-Mustasimi from the last Abbasid era was the fountainhead for the Ottoman calligraphers. Yaqut al-Mustasimi had practiced the six traditional scripts. The most sought-after accomplishment for calligraphy from the Othman era had to do with copying the Quran and designing the inscription that decorated the interior of the mosques. The Tugra style of script had a special feature that highlighted Othman calligraphy. Brend (1991,p65) states that "the tugra was used as the sign of the sultan on documents, coinage and inscriptions on buildings".

\subsection{TRADITIONAL ISLAMIC CALLIGRAPHY PAINTING AND MODERN CALLIGRAPHERS}

Traditional Islamic calligraphy Painting is a work of art that is formed in a two-dimensional manner or mode. These paintings evoke a feeling of aesthetic considerations about the harmonious aspect or viewpoint of the two-dimensional plane that expresses the Arabic language from an artistic perspective. The quality of drawing the lines and the traditional color palates of the dark and bright is a very important element of the painting. Traditional Islamic Calligraphy is a kind of Islamic art that has been produced by modern Islamic calligraphers and it focuses on its spiritual essence as it relates to the writing of some of the verses of the Quran. These calligraphers went 
about designing and creating many various calligraphic paintings based on the previous generations of Islamic calligraphers. This traditional painting generally follows the main aspects and characteristics of the past productions of Islamic calligraphy.

The modern calligraphers focused on the rules of writing classic calligraphy and they also used traditional tools as well. Modern Islamic calligraphers are inspired by the well-known six styles of classical Arabic calligraphy. The six pens for calligraphy have strict rules and a method that is used in order to apply and to create a traditional calligraphic painting. The most famous style that had been used in the past by Islamic calligraphers included the Kufi and the Thuluth style. They are inspired by the Kufi style because this style was the first style for writing the Quran and it has artistic features. According to Oweis Fayeq (2002:p76) the Kufic style is noted for its proportional measurements, angularity and squareness and it is well known as one of the earliest styles to be used to record the Quran.

Islamic calligraphy painting is considered decorative handwriting with a deeper illogical meaning. For centuries Muslim have considered this tradition of calligraphy as a sacred art. Calligraphy painting in Islam is a way of artistic expression. Muslim calligraphers made it their mission to develop more types and methods to create calligraphy. In general, traditional calligraphy painting is used to write some verses from the Quran as well as words from the prophet. This is known as hadith.

Tradition calligraphy painting involves a long process that is carried out to draw a letter, in fact, the Arabic letters are based on the human body (Oweis,2002:p90). Creating a painting is a very challenging process and it necessitates quite a lot of practice, in other words, this art is considered as a labor-intensive art because it requires many hours to draw on a sheet of paper. Islamic calligraphers produce tradition calligraphy painting in its sophisticated form that follows the golden rule of writing. Modern calligraphers who are influenced by the traditional calligraphy art use very strict and well-established regulations and rules.

Generally, modern Islamic calligraphers nowadays practice many kinds of styles for writing calligraphy, such as, Thuluth, Naskh, Farsi, Deewani, and Riqa'a. These styles are famous for their cursive letters and forms. The Muslim calligraphers use these six styles as ornamental scripts to produce a painting. The six styles of Arabic calligraphy are considered the most famous styles that are presenting in traditional calligraphy painting.

Arabic calligraphy considered as an art form as well as the major and unifying element in Islamic art. Also, Islamic architecture has a symbolic connection to the word of God. The most appreciation calligraphic pieces which contain Quranic verses and names of God that are common in Islamic culture. (Oweis ,2002: p76).

Traditional calligraphers are using tradition tools and mediums that are influenced by Asian cultures. The primary tools to create traditional calligraphy painting include the reed or bamboo pens and ink. Even though calligraphers usually used black ink or other colors, black ink is the most prominent color of ink that was used a long time ago, then later colored inks began to be used. Calligraphers applied their composition of calligraphy art on vellum, paper, silk, and linen, so all these mediums have been used as a part of traditional Islamic calligraphy painting.

Most traditional modern calligraphers work on paper, especially writing verses from the Quran. There are some examples of modern calligraphers who are working with these traditional styles and techniques to create a calligraphy painting. One modern calligrapher, Haji Noor Deen, a Chinese artist, born in China in 1963, is influenced by traditional Islamic calligraphy. Noor Deen 
has mastered traditional Islamic calligraphy and he creates a unique calligraphy painting, that presents the beauty of this art. Noor Deen has been teaching traditional calligraphy and Islamic art to a modern audience. (Haji,2015:p3) An example of Noor calligraphic art work is presenting on Figure 1

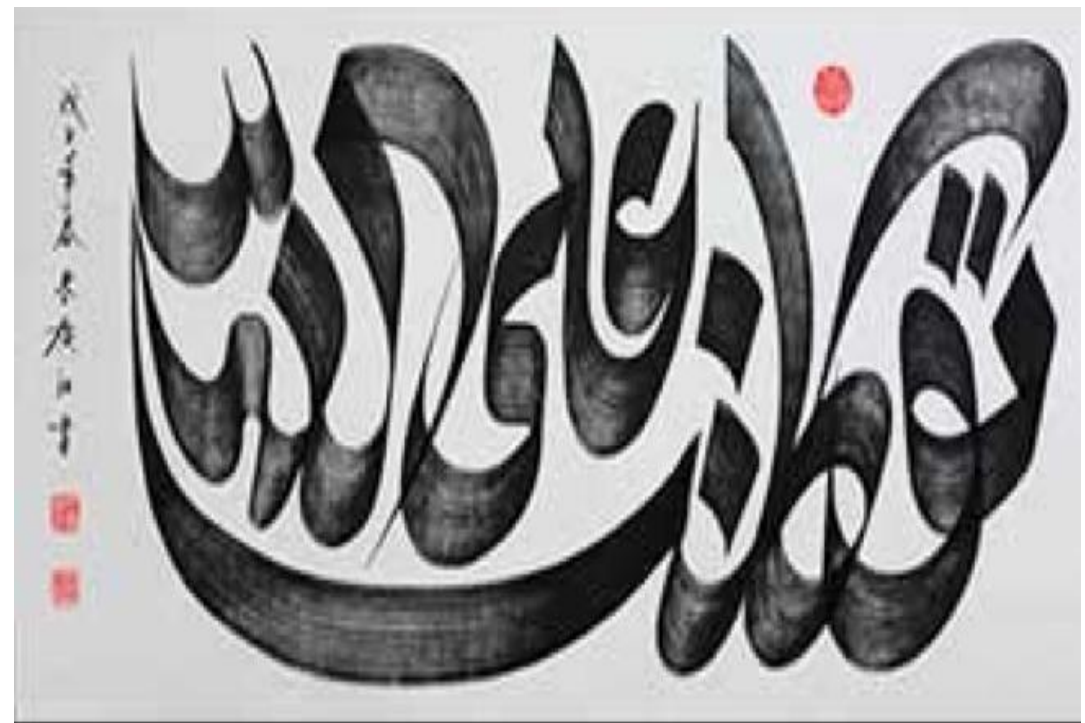

Figure 1 Haji Noor Deen,My Trust in Allah, ink on paper, 230 x 102 cm, 2008. (hajinoordeen.com).

One of the most remarkable and well-known calligraphers from the United States who is influenced by tradition Islamic calligraphy is Mohamed Zakariya. Zakariya combines traditional standards with a modern sensibility to produce calligraphy painting that is presented on paper. $\mathrm{He}$ uses traditional tools and styles to write Islamic calligraphy and he has introduced a classic calligraphy style of painting that emphasizes the Arabic language and the religion of Islam. Zakariya is known as the ambassador of the art of Islamic calligraphy in America. (Zakariya,2015:p3). An example of Zakariya calligraphy art work can be seen on Figure 2.

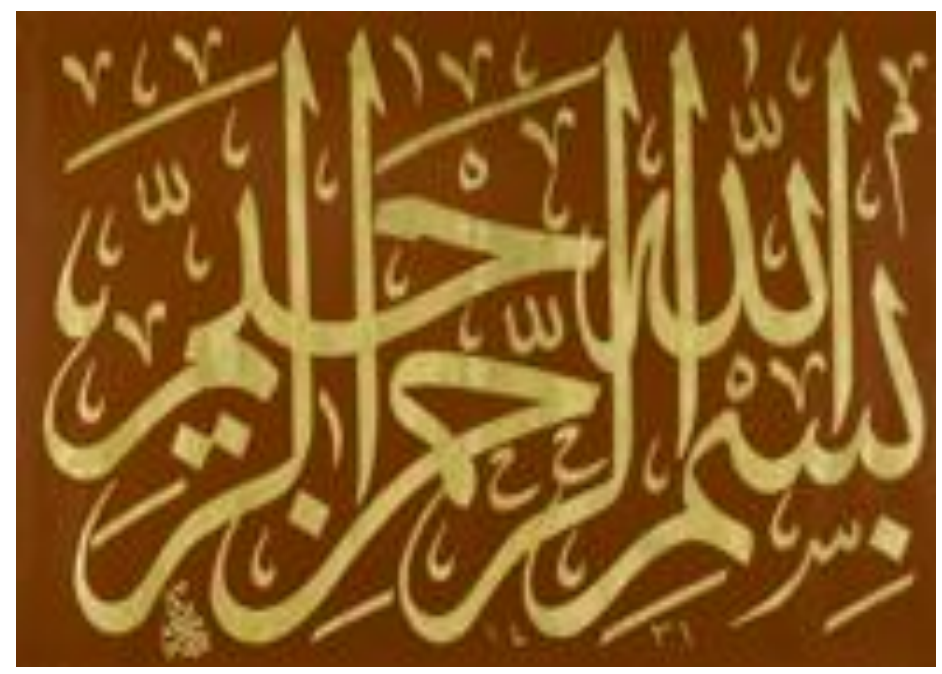

Figure 2 Mohammed Zakariya, In the Name of God, Universally Merciful, Specifically Merciful, Green gold lead, Taracloth, natural red Italian earth with acrylic, 42x 28 inch, 2010. (zakariya.net).

Nabil Safwat (Zakariya,2015:p4) states that "Although he is a master of the classical Arabic scripts and well-grounded in the historical styles, Zakariya has reinterpreted the tradition through the lens of his own artistic sensibility, bringing to his calligraphy a sophisticated color sense, 
confident strength of composition, and controlled yet fluid movement of line. The result is work that resonates with people of all backgrounds. With its combination of aesthetics and meaning, Zakariya believes, calligraphy has the power to touch people profoundly". In traditional Islamic calligraphy painting, calligraphers are researching some colors that are important to Muslim society and express tradition Islamic art. The colors in Islamic calligraphy painting are associated with Islamic culture and faith.( Faruqi, 1986,p90).

Traditional calligraphy painting is associated with the Islamic religion. The large geographical background of Islamic calligraphers is evidence to present how traditional Islamic art has affected each culture. Each calligrapher has a distinct calligraphic style to write calligraphy. The tradition of calligraphy painting demonstrates diversity and complexity in its designs and forms. The long history of Islamic art has influenced modern Islamic calligraphers and directed them to create painting that expresses a classical feeling of spirituality with a contemporary ethos.

\subsection{CONTEMPORARY ISLAMIC CALLIGRAPHY PAINTING AND MODERN CALLIGRAPHERS}

Contemporary Calligraphy painting is a way of expressing the art of Islamic calligraphy from a new perspective. Calligraphers begin to search more, and experiment by creating a contemporary painting based on Islamic calligraphy. Islamic calligraphy art is a visual tool that is presented utilizing Arabic script. In recent years, modern calligraphers have emerged and created a movement whereby they have distanced themselves from the strict rules that were used to draw the traditional calligraphy and they are creating new rules, that differ and vary from the old grammar and rules, that feature the new contemporary calligraphy.

Contemporary calligraphy painting means a style that is full of a lively dynamic and a charismatic creativity to create a work of art. Contemporary calligraphy styles have characteristics that are different from one region to another. The calligraphers today show diversity based on certain adaptive variation influences from the Islamic world. Many contemporary Islamic calligraphers deal with Arabic script, while others focus on the movement of the words. Contemporary calligraphy painting is based on the Arabic language and it represents a method that is from the point of view of a modern perspective.

Nja Mahdaoui, one of the famous contemporary calligraphers, has been influenced by traditional Arabic calligraphy. Mahdaoui, a Tunisian calligrapher, considers himself 'an explorer of signs. His calligraphy paintings are a kind of abstraction that use Arabic letters and words as an important element. Tradition Islamic calligraphy is an inspiration that leads Mahdaoui to create abstract compositions based on the traditional style of calligraphy.

Mahdaoui, through his choice of materials and the medium, expresses his concept beyond the artwork in his contemporary painting. The materials and the medium have become an important element and play a significant role as they assist to convey his messages. He works with contemporary and traditional materials, such as, canvas, vellum, papyrus, arches paper, silkscreen prints, sculptures, aluminum, drums, textiles, and tapestry. As stated in the book, Artist of the Modern Middle East, "Nja Mahdaoui does not paint, he writes but he does not write... Arabic calligraphy yes and no. Yes, in the fluidity of the shapes. No in the reading of it". Figure 3 is presenting one of the Mahdaui calligraphy art work. 


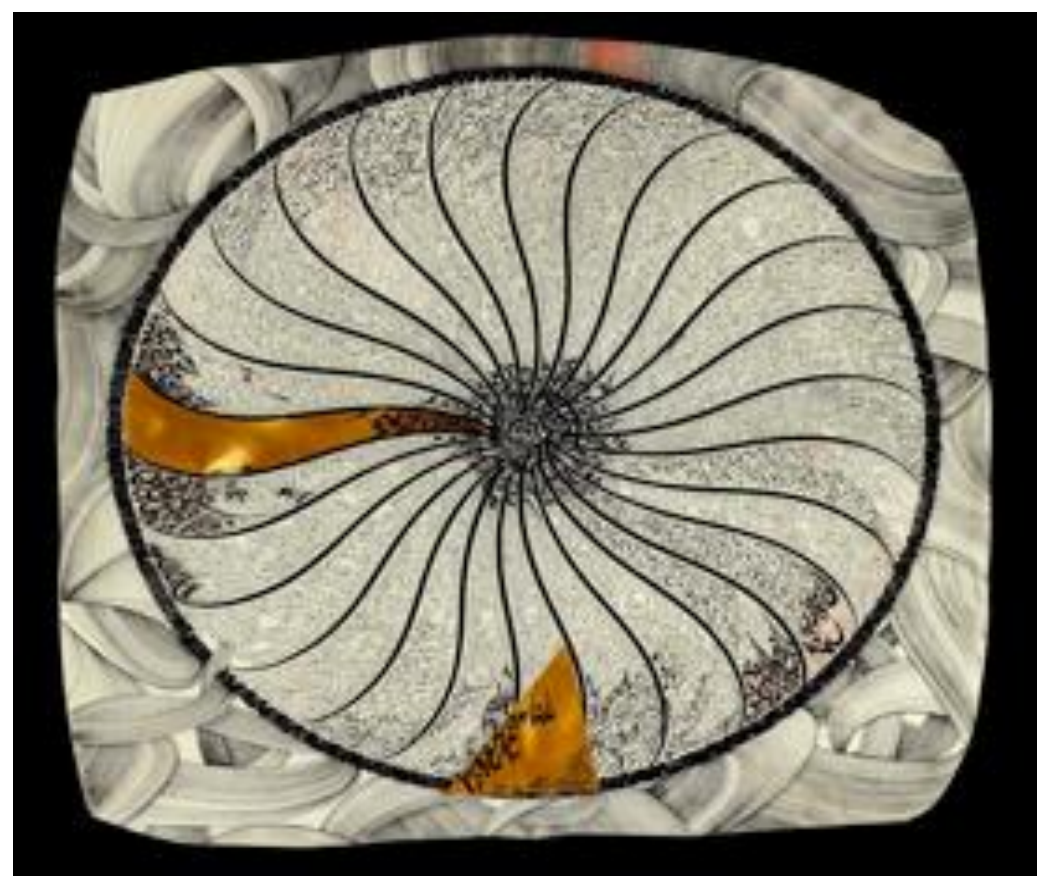

Figure 3 Nja Mahdaoui, Untitled, Parchment, china ink, gold and silver, 90 x90 cm, 2007. (nja-mahdaoui.com).

Most of Mahdaoui's calligraphy paintings are based on the traditional style of the Kufic calligraphic script. Aside from this, Mahdaoui creates his painting in a unique contemporary manner. In other words, he is focusing on the aesthetic aspect of the shapes of the Arabic letters, without focusing on the meaning of the words, to convey intricate and complex forms. Even though he is influenced by traditional colors that are common in traditional Islamic painting, he delivers it through a contemporary context. Mahdaoui is the leader of Muslim contemporary calligraphers and his calligraphic painting has influenced other contemporary calligraphers. Mahdaoui draws upon the history of traditional Islamic calligraphy as a basic element to produce contemporary painting.

Hassan Massoudi, a contemporary Iraqi artist, has been influenced by Arabic calligraphy. Massoudi's calligraphy painting involves the mixing of the traditional and modern styles of the classic roles of calligraphy. He focuses on the quality of the lines as a dynamic force through his painting. His painting is considered as abstract contemporary calligraphy. Massoudi's paintings express emotion through the movement of the lines. Massoudi is a classical master calligrapher, who provokes the contemporary calligraphers to combine the modern style combined with the traditional style to create wonderful calligraphy painting. Massoudi's painting is a kind of classic calligraphy, even though it is referred to as contemporary painting. In other words, while he is inspired by the classical calligraphy, he is changing the rules to create new visual meaning. An example of Massoudy Arabic calligraphy art work is presenting on Figure 4. 


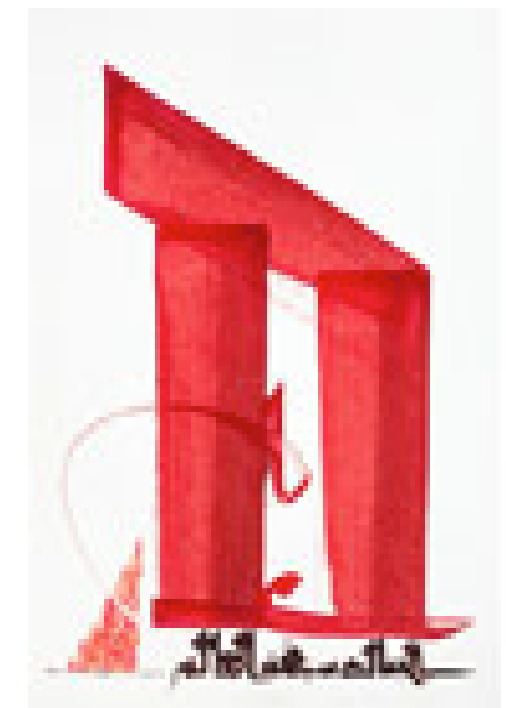

Figure 4 Hassan Massoudy, Beauty Will Save the World, Water-based pigments on paper, 75x $55 \mathrm{~cm}, 2008$. (http://hassan.massoudy.pagespersoorange.fr).

Ahmed Mustafa, a contemporary calligrapher, uses the Quranic text in most of his paintings. Mustafa is an Egyptian calligrapher. Mustafa, inspired by the sacred Qur'anic verse, states that "Western art deals with the casual, rather than what I call the immutable essence. As Michelangelo said, 'Good painting is nothing but a copy of the Perfection of God." Moustafa's calligraphy painting combines the classic with the contemporary as well as Western painting with an Islamic tradition. Also, through his work, Moustafa's paintings represent a sacred and spiritual space that comes from the holy Quran. His painting incorporates language, in an abstract contemporary style, by changing traditional calligraphy to an artistic language.

Poems play an essential role in contemporary calligraphy. In the process of transforming the words, the words lose their readability and the significance becomes a form of melody that transforms into a piece of art. Contemporary Muslim calligraphers are expressing their ideas and concept of language in which complexity and symmetry emerge from painting. In terms of their message they convey by creating contemporary calligraphy, it is to convey the principles of faith and spirit based upon Islamic belief.

The medium of painting in contemporary calligraphy could be canvas, paper, and board. Most innovative calligraphers have produced paintings which are displayed on the walls. The media for contemporary calligraphy can be oil or acrylic paints, sometimes secular texts shaped in design to create a calligraphic painting. Calligraphy painting is known for its multiple repetitions and swirling forms. Barbara Brend (1991:p32) states the "universal repetition of [the] prayer formula suggests that calligraphy is the fabric of the world".

Contemporary Islamic calligraphy painting is the most recognizable form of art created by modern Muslim calligraphers, who are influenced by traditional calligraphy. The aesthetic aspect of contemporary calligraphy is represented by the fluid elegance of the Arabic letter lines. Modern calligraphers are expressing, by way of their art, the concept of faith and spirituality. Moreover, modern calligraphers combine the holy text of the Quran into their painting, in a way to convey the message of spiritual quality. This displays the aesthetic purpose of contemporary calligraphy.

Calligraphy painting is presenting the aesthetic value of Islamic art through complex linear formations. The harmonious forms of painting are illustrated utilising traditional and contemporary colours. The composition of the calligraphy painting is famous for the intertwining and interplay between the letters and the words that appear in an ornamental way of drawing. Page $\mid 9$ 
Indeed, contemporary calligraphy painting provides a variety of decorative and Islamic motifs that enhance the surface of the painting. Contemporary calligraphers experience a new form of expression by depicting the letters in a complex composition that is combined with the modern

\subsection{CONCLUSION}

The art of calligraphy began from the beginning of the Islamic world and there are many remarkable calligraphers who are painting and who are still famous until this day (Emerick, 1998:p90). In other words, the art of calligraphy has been presented since ancient times and Muslim calligraphers express their creativity and ability through their unique calligraphic paintings. The most significant aspect of Islamic art is calligraphy and this art has developed into a traditional and a contemporary form. Also, Islamic calligraphy is considered the finest of all kinds of Islamic art. Calligraphy is the art of elegant handwriting.

Islamic calligraphers have displayed many styles of Arabic calligraphy that contain intricate lines and rich colours. Calligraphers have been using the form of letters and words as a visual pictorial and it focuses on the spiritual aspect and it has a certain aesthetic value. Islamic calligraphy painting expresses the expression and creativity of Muslim artists. Traditional and contemporary calligraphy painting represents the beauty and power of the Arabic language. Contemporary and tradition calligraphers are inspired by the verses of the Quran, some Arabic poems and some wise words. In general, calligraphers start their journey to create their painting by inspiring the words that they read. The calligraphic marks of tradition and contemporary painting express movement and dynamism.

Calligraphy painting demonstrates the aesthetic principles of Islamic culture as well as demonstrate the simplicity and complexity of Islamic art. Moreover, calligraphy painting presents the spiritual dimension of Islam through a splendid form of art. Calligraphers connecting their painting to the Arabic language, this language has a universal spirituality all over the Islamic world. Contemporary calligraphers use canvas as a page of a book that reveals the abstract design of the lines and shapes.

They use the letters and words as a starting point to create their abstract composition by the repetition of words and letters to achieve a new meaning beyond language. On the other hand, traditional calligraphers use conventional tools and techniques to build up their painting. Barbara Brend (1991:p54) reveals that "traditional Islamic painting, like writing at its simplest level aims to be precisely legible". The aesthetic principles of tradition and contemporary painting demonstrate the Arabic language and Islamic civilization in a sophisticated method.

\section{List of Reference}

Afifi, F. S. (1990). “Al-Ketubah al-Muta akisab” [The Mirrored Image script]. Egypt: Maktabah Mamduh.

Afifi, F. S. (1992). “Al-Khet al-Thulth” [Thuluth script]. Egypt: Usama li al- Nash Tauzin.

Blair, Sheila. (2006). Islamic Calligraphy. Edinburgh: Edinburgh University Press.

Brend, Barbara. (1991). Islamic Art. Cambridge, Mass: Harvard University Press.

David, J. (1989). Calligraphy: The Geometry of the Script in Saudi Aramco World. Sept/Oct, 16-27.

Dutton, Yasin. (2007). Islamic calligraphy. Bulletin of the School of Oriental and African Studies, University East. London: British Museum Press.

Education Association. Stable, URL: https://www.jstor.org/stable/3193986. 
Faruqi, I. \& Lois L. (1986). "The Cultural Atlas of Islam”. American Journal of Islamic Social Sciences, 40(4), 20.

Fayeq, Oweis. (2002). Art as an Educational Tool about the Teaching of Islam. Published by: National Art Federation of KSI Muslim Communities United Kingdom.

Fu, S., Lowry, G. D., \& Yonemura, A. (1986). "From concept to context”. Freer Gallery of Art, Smithsonian

Ghulam, Yousif Mahmud. (1982). The art of Arabic calligraphy. Lafayette, Ca. (P.O. Box 853, Lafayette Haven [Conn.]: Yale University Press.

Haji Noor Deen's home page, accessed April17, 2015, http://www.hajinoordeen.com/ artist/artist.html.

Hassan Massoudy, Massoudy Calligraphe (homepage),n.d,accessed April 17, 2015, http://hassan.massoudy.pagesperso--- orange.fr/english.htm.

Jafar, M. (2002). “Arabic Calligraphy: Naskh Script for Beginners”. British Museum Press.

Khalid, H (2016). The genius of Uthaman Taha https://khalid-hussain.github.io/post/the-genius-of-UthmanTaha-Mushaf/ Accessed on 21th, October 2019.

Khalid, M (2000). Arabic Calligraphy http://islamicart.com/main/calligraphy/intro.html Accessed on 20 October, 2017

Khatibi, A. \& Sijelmassi, M. (1976). "The splendor of Islamic calligraphy”. Thames \& Hudson. London.

Khatibi, Abdelkebir, and Mohamed Sijelmassi. (1996). The splendor of Islamic calligraphy. New York: Thames Metropolitan Museum of Art. New York.

Minorsky, V. and Wheeler M. T. (1959). Calligraphers and Painters-A Treatise by Qadi Abmad, son of Mir-Munshi. (circa AH 1015/AD 1606).Washington.

Zakariy, Mohamed. (2015). The Art of Islamic calligraphy, Mohamed Zakariya's homepage, accessed 17 April, 2015, http://www.zakariya.net.

Moustafa, Ahmed. (2015). The Art of Arabic Calligraphy.Moustafa, Ahmed.“Homepage.”Accessed April 17, 2015. http://www.fenoon.com/ artist/artist.html.

Najda. (1994). “Arabic Calligraphy.” Women Concerned about the Middle East 94707th ser, 1-5.

Nja Mahdaoui, “Letters and Calligraphy,” International Exhibition of Calligraphy, accessed April 17, 2015, available at: http://calligraphyexpo.com/eng/Personalities/Participants/Nja_Mahdaoui/Article.

Nasr, S. H. (1987). Islamic Art and spirituality. New York: State University of New York Pre.

Nasruddin, S. (2004). an Exbibition of Agfan Calligrapby and Miniature Painting. Dublin, Har Centre Library P.315.

Porter, Venetia, Isabelle Caussé, and British Museum. (2006). Word into Art: Artists of the Modern Middle, $57-$ 82.

Razwy, S. A. A. (2014). “A Restatement of the History of Islam and Muslims". Lulu Press, Inc. World

Safadi, Y. H. (1978). "Islamic Calligraphy". London: Thames and Hudson.

Saliu, B. A (2006). Aspects of Kano Cultural Tourism. (ed) in Perspective on Kano

Schimmel, A. (1970). "Islamic Calligraphy”. Leiden: E.J. Brill Archive.

Schimmel, A. (1975). "Mystical Dimensions of Islam”. University of North Carolina press.

Schimmel, Annemarie. (1990). Calligraphy and Islamic Culture. New York: New York University Press.

Sloman, Paul. (2009). Contemporary Art in the Middle East. London: Black Dog. Typography." Design Issues 19(2), 60-63. 